\title{
Influence of various parameters on the sensitivity of precipitin tests in farmer's lung by immunodiffusion and immunoosmophoresis ${ }^{1}$
}

\author{
J. E. JAMESON \\ From the Public Health Laboratory, Brighton
}

SYNOPSIS Dilutions of a standard serum were made in saline and in negative sera, and comparative tests by immunodiffusion and by immunoosmophoresis were made against one antigenic component of Micropolyspora faeni (Thermopolyspora polyspora). The endpoint dilution of the standard serum in saline and serum in wells of different sizes was ascertained in each test. The endpoint dilution was unaffected by the distance of separation (from $1.5 \mathrm{~mm}$ to $6 \mathrm{~mm}$ ) between the origins of serum and antigen, provided that the tests were read at times appropriate to each separation, the greater separations requiring longer periods of development. Higher endpoint dilutions were obtained by the use of $1 \%$ Noble agar in immunoosmophoresis than with $1 \%$ Ionagar no. 2 (Oxoid). This difference was more noticeable when low osmophoresis potentials were used.

Precipitin tests for farmer's lung generally involve a multiplicity of antigen-antibody reactions. Owing to the results on precipitin band formation of excesses of various individual reactants, it is difficult to obtain valid numerical comparisons of the relative sensitivities of different methods. This difficulty was overcome by using tests involving a single antigenantibody reaction. The $\mathrm{A} 1$ antigen component of Micropolyspora faeni was used at its minimum reacting concentration (Jameson, 1969).

\section{MATERIALS AND METHODS}

Immunodiffusion and immunoosmophoresis tests were carried out as described in the accompanying paper (Jameson, 1969) except that parameters were varied as described below. A series of special jigs and cutters made in the laboratory were used to obtain the appropriate patterns of wells and slots.

IMMUNODIFFUSION Serum wells were accurately cut in the following diameters: $20 \mathrm{~mm}, 16 \mathrm{~mm}, 12.5 \mathrm{~mm}, 10 \mathrm{~mm}$, $8 \mathrm{~mm}, 6 \mathrm{~mm}$, and $4 \mathrm{~mm}$. With the four smaller serum wells, six antigen wells of $4 \mathrm{~mm}$ diameter were used in each test; these were filled with $\mathrm{N} / 4, \mathrm{~N} / 8, \mathrm{~N} / 16, \mathrm{~N} / 32$, $\mathrm{N} / 64$, and $\mathrm{N} / 128$ dilutions of the broth culture extract of $M$. faeni (Jameson, 1968). Four antigen wells, ie, omitting the N/4 and N/128 dilutions, were used in conjunction with the $20 \mathrm{~mm}, 16 \mathrm{~mm}$, and $12.5 \mathrm{~mm}$ serum wells.

${ }^{1}$ A report to the working party on farmer's lung of the Public Health Laboratory Service.

Received for publication 31 December 1968.
Separations between serum and antigen origins were $1.5 \mathrm{~mm}, 3 \mathrm{~mm}, 5 \mathrm{~mm}$, and $6 \mathrm{~mm}$ respectively. Tests were incubated at $25^{\circ} \mathrm{C}$, variously for six hours, 18 hours, 24 hours, 48 hours, 72 hours, and 120 hours.

Serum wells were filled with doubling dilutions from $1 / 16$ to $1 / 512$ of a standard serum, as used in the precipitin inhibition test (Jameson, 1969). Dilutions of the standard serum were made in physiological saline, and also in two pools of negative sera. Two intermediate serum dilutions at $1 / 180$ and $1 / 360$ were also used.

IMMUNOOSMOPHORESIS Serum slots were cut in 1 in. $(25 \mathrm{~mm}), \frac{1}{2}$ in. $(12 \mathrm{~mm})$, and 1 in. $(6 \mathrm{~mm})$ lengths and with $1 / 16$ in. $\left(1 \frac{1}{2} \mathrm{~mm}\right), \frac{1}{8}$ in. $(3 \mathrm{~mm})$, and $\frac{1}{4}$ in. $(6 \mathrm{~mm})$ widths. Circular serum origins were also cut in sizes of $10 \mathrm{~mm}, 8 \mathrm{~mm}, 6 \mathrm{~mm}$, and $4 \mathrm{~mm}$ diameter. Separation between antigen strips and serum origins was $\frac{5}{8}$ in. except when otherwise specified. The antigen strips were impregnated with the N/64 concentration of the broth culture extract of $M$. faeni. The power pack was used at a constant current setting of $1 \mathrm{~mA}$ per slide except when otherwise stated. Dilutions of the standard serum were as in the immunodiffusion tests.

\section{SUMMARY OF RESULTS}

IMMUNODIFFUSION (a) Constant separation $(5 \mathrm{~mm})$ between serum and antigen origins. Variations on sizes of serum wells. Maximum readings after any time of incubation. In the range of serum well diameters of $4 \mathrm{~mm}$ to $10 \mathrm{~mm}$ inclusive, the endpoint dilutions of the standard serum in saline varied directly 


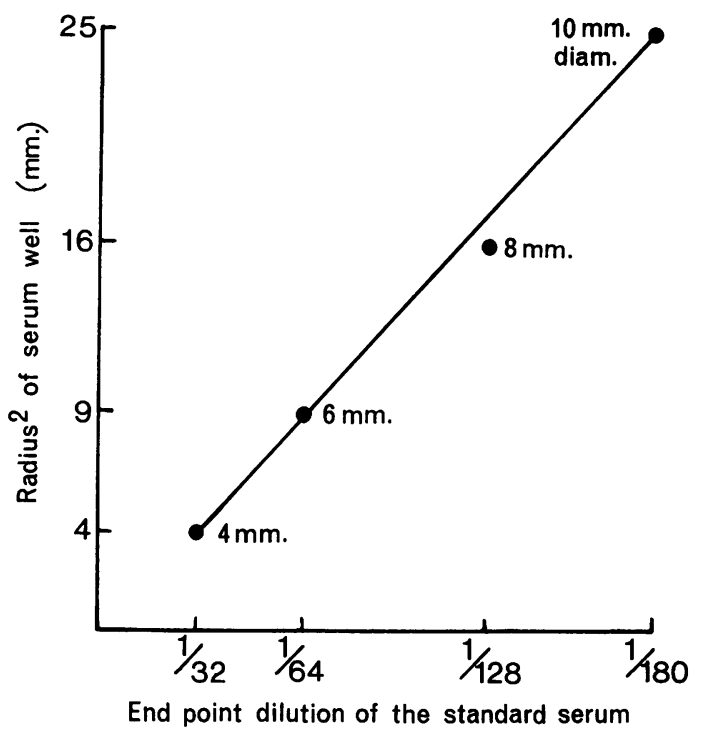

FIG. Endpoint dilutions, by immunodiffusion, of the standard serum plotted against the squares of the radii of the serum wells.

with the square of the radius of the serum wells (see Figure). The highest endpoint dilution $(1 / 180)$ was reached with the $10 \mathrm{~mm}$ diameter serum well. No further increase in this endpoint dilution was found by using serum wells of $12.5 \mathrm{~mm}, 16 \mathrm{~mm}$, and $20 \mathrm{~mm}$ diamster respectively. In general the same law applied with the dilutions of the standard serum in each of the two pools of negative sera, though in most instances these endpoints were one doubling dilution lower. This was because faint arcs of precipitation tended to become indistinguishable from the non-specific staining which surrounded serum origins. No corresponding non-specific staining was present when dilutions in saline of the standard serum were used.

(b) Constant serum well diameter $(8 \mathrm{~mm})$. Variation in distances of separation between serum and antigen origins. Maximum readings after any time of incubation. Within the parameter ranges tested (separations from $3 \mathrm{~mm}$ to $6 \mathrm{~mm}$, incubation from 24 hours to 120 hours), the endpoint dilution of the standard serum in saline was constant $(1 / 128)$, irrespective of the separation. Endpoint dilutions in pools of negative sera were generally one doubling dilution lower than corresponding dilutions in saline.

(c) Constant serum well diameter $(8 \mathrm{~mm})$. Constant separations between serum and antigen wells. Variable times of incubation. With separations not exceeding $3 \mathrm{~mm}$ the maximum endpoint dilutions of the standard serum in saline were reached by 18 hours. With $6 \mathrm{~mm}$ separation the endpoint dilution after
48 hours was about one half doubling dilution. higher than that obtained after 24 hours. No measur $\overrightarrow{\overline{\vec{c}}}$ able increase in the endpoint dilution was found by prolonging the incubation period beyond 48 hourse With a separation of $1.5 \mathrm{~mm}$ and a serum well of $10 \mathrm{~mm}$ diameter the endpoint dilution obtained after six hours was $1 / 180$, the same endpoint dilution as was obtained after 24 hours, or longer incubationw of otherwise identical tests.

IMMUNOOSMOPHORESIS As distinct from the immunos diffusion tests, no significant differences were foun between the endpoint dilutions of the standar ${ }^{\$}$ serum in saline and the corresponding dilutions in each of the two pools of negative sera.

The endpoint dilutions obtained from slots of various sizes are set out in Table I.

TABLE I

ENDPOINT DILUTIONS OBTAINED BY IMMUNOOSMOPHORESE WITH SERUM SLOT ORIGINS OF VARIOUS MEASUREMENTS

\begin{tabular}{|c|c|c|c|}
\hline \multirow{2}{*}{$\begin{array}{l}\text { Serum } \\
\text { Slot } \\
\text { Width } \\
(\mathrm{mm})\end{array}$} & \multicolumn{3}{|c|}{$\begin{array}{l}\text { Serum Slot } \\
\text { Length }(\mathrm{mm})\end{array}$} \\
\hline & 6.4 & $12 \cdot 7$ & $25 \cdot 4$ \\
\hline $\begin{array}{l}1.6 \\
3.2 \\
6.4\end{array}$ & $\begin{array}{l}1 / 64 \\
1 / 128 \\
1 / 128\end{array}$ & $\begin{array}{l}1 / 128 \\
1 / 256 \\
1 / 256\end{array}$ & $\begin{array}{c}1 / 128 \\
1 / 256 \\
1 / 256\end{array}$ \\
\hline
\end{tabular}

Tests were conducted with three 1 in. $\times 1 / 16$ in serum slots per slide, containing $1 / 32,1 / 64$, and $1 / 128$ dilutions respectively of the standard serum i saline. Osmophoresis was carried out with antige strips impregnated with $\mathrm{N} / 32, \mathrm{~N} / 64$, and $\mathrm{N} / 12 \mathrm{~g}$ concentrations of $M$. faeni antigen. The agar was buffered with normal strength barbiturate buffer at pH 8.6 (Jameson, 1968), and with like buffers af half and twice normal strength. Tests with norma strength buffer were run at $0.5,1.0$, and $2.0 \mathrm{~mA}$ perf slide; with $\mathrm{N} / 2$ buffer they were run at $0 \cdot 25,0.5$, an $1.0 \mathrm{~mA}$ per slide and with $2 \mathrm{~N}$ buffer at 1,2 , and $4 \mathrm{~mA}$ per slide. Within these limits there were no conspicuous differences in the results obtained, though the maximum endpoint dilution $(1 / 128)$ was arrived at in only four instances: (1) $\mathrm{N} / 1$ buffer, $1 \mathrm{~mA}$, pee slide, N/64 antigen; (2) N/1 buffer, $2 \mathrm{~mA}$ per slided $\mathrm{N} / 32$ antigen; (3) N/2 buffer, $0.5 \mathrm{~mA}$ per slide, $\mathrm{N} / 128$ antigen; (4) N/2 buffer, $1 \mathrm{~mA}$ per slide N/64 antigen. An endpoint of 1/64 was obtained in all the other slides. The ranges of the above pare meters were exceeded in two cases, that is, slides buffered with $\mathrm{N} / 2$ buffer were also run at $2 \mathrm{~mA}$ pexy slide and $4 \mathrm{~mA}$ per slide respectively. In both these cases no arcs of precipitation were seen with an of the three dilutions of the standard serum.

All the above tests were also carried out with 18 Oxoid Ionagar no. 2. The maximum endpoint dilus 
tion reached with this agar was $1 / 64$. This endpoint was reached with each of the two higher osmophoresis potentials applied to buffers of all three ionicities, but was not reached with $\mathrm{N} / 2$ buffer at $0.25 \mathrm{~mA}$ per slide, $\mathrm{N} / 1$ buffer at $0.5 \mathrm{~mA}$ per slide, and $2 \mathrm{~N}$ buffer at $1 \mathrm{~mA}$ per slide. In the latter instances the endpoint dilution was $1 / 32$.

Three slots of $\frac{5}{8}$ in. $\times 1 / 16$ in. per slide in $N / 1$ buffer were used and filled with standard serum dilutions in saline $(1 / 64,1 / 128$, and $1 / 256)$. Antigen strips were impregnated with $\mathrm{N} / 32, \mathrm{~N} / 64$, and $\mathrm{N} / 128$ concentrations of $M$. faeni extract. Osmophoresis was run at $1 \mathrm{~mA}$ per slide. Antigen strips were separated from serum origins by $\frac{1}{8}$ in., $\frac{1}{4}$ in., $\frac{1}{2}$ in., $\frac{3}{4}$ in., and 1 in. respectively. The endpoint dilutions arrived at varied little within this range of separations, and no increase in sensitivity was obtained by the use of the shortest separation $\left(\frac{1}{8} \mathrm{in}\right.$.). Reduction in sensitivity was observed at both extremes of the range, that is, at $\frac{1}{8}$ in. and 1 in. The optimal separations appeared to lie within the range most commonly used, namely, $\frac{1}{2}$ in. to $\frac{3}{4}$ in.

The endpoint dilutions obtained by use of wells of various diameters are set out in Table II.

\section{TABLE II}

ENDPOINT DILUTIONS OBTAINED BY IMMUNOOSMOPHORESIS WITH CIRCULAR SERUM ORIGINS OF VARIOUS DIAMETERS

\begin{tabular}{cl}
$\begin{array}{l}\text { Serum Well } \\
\text { Diameter } \\
(\mathrm{mm})\end{array}$ & $\begin{array}{l}\text { Endpoint } \\
\text { Dilution } \\
\text { of Serum }\end{array}$ \\
\hline 4.0 & $1 / 90$ \\
6.0 & $1 / 180$ \\
8.0 & $1 / 256$ \\
10.0 & $1 / 256$
\end{tabular}

\section{DISCUSSION}

When dilutions of the standard serum in saline were used, reproducible endpoint dilutions were obtained in the immunodiffusion tejts. Dilutions in negative sera, or undiluted sera, gave a variable amount of non-specific staining in the stained preparations. The degree of this non-specific staining varied not only between different sera, but also with the periods of incubation of the tests and with the immunodiffusion buffers used. The average result of this threedimensional variability was to lower the endpoint dilution compared with that obtained with dilutions in saline by about one doubling dilution. A consequence of this variability is that it is not possible to lay down an optimal immunodiffusion test which would be applicable to all sera, except in respect of the size of the serum origin. The latter dimension, at least, ought therefore to be specified when results of immunodiffusion tests are quoted.

The maximum endpoint dilution obtained by im- munodiffusion with the standard serum in saline was $1 / 180$ using a serum well $10 \mathrm{~mm}$ in diameter. No further increase in sensitivity was found by increasing the diameter of the serum well. Variations in the sizes of wells up to $10 \mathrm{~mm}$ in diameter influenced the sensitivities of the immunodiffusion tests far more than did variations in the other parameters. The endpoint dilutions obtained in saline were not influenced by the distances of separation (from 1.5 $\mathrm{mm}$ to $6 \mathrm{~mm}$ ) between the serum and antigen origins, provided that the tests were read at the times most appropriate to each separation. Owing to the larger number of unintended experimental variations which may occur during immunoosmophoresis, the endpoint dilutions obtained by this method were more liable to fluctuation than in the immunodiffusion tests with serum dilutions in saline. The impact of non-specific staining was, however, negligible in immunoosmophoresis, endpoint dilutions obtained when negative sera were used as diluents being no lower than those obtained by immunoosmophoresis with dilutions of the standard serum in saline. When slotted serum origins were used no advantage was detected with slots greater than $\frac{1}{2}$ in. in length or $\frac{1}{8}$ in. width. The endpoint, either in saline or negative serum, from a slot $\frac{1}{2}$ in. $\times \frac{1}{8}$ in. was $1 / 256$, one half doubling dilution higher than that obtained by immunodiffusion. Although the endpoint from a slot $\frac{1}{2}$ in. $\times 1 / 16$ in. was only $1 / 128$, one half doubling dilution lower than that obtained by immunodiffusion of the standard serum diluted with saline, it was generally one half doubling dilution higher than that obtained by immunodiffusion of the same serum diluted with negative serum. With the use of circular serum origins, maximum sensitivity in immunoosmophoresis was reached (an endpoint of 1/256) by the use of a serum origin $8 \mathrm{~mm}$ in diameter. No further increase in sensitivity was detected with a serum origin of $10 \mathrm{~mm}$.

Because of the tendency to experimental variation referred to in the preceding paragraph, too much significance should not be read into the results of the single experiments on the influence of ionicity, osmophoresis potential, type of agar, and distance of separation. For this reason, only trends which seemed to be fairly well established were quoted in the results. There seems, for example, little doubt that immunoosmophoresis tests carried out in $1 \%$ Noble agar were rather more sensitive than corresponding tests with $1 \%$ Ionagar, particularly at low osmophoresis potentials. For similar reasons the optimal $\frac{1}{2}$ in. length of the slotted serum origin in, immunoosmophoresis, arrived at in this paper, should not be followed too rigidly. A true, though here undetected, small increase in sensitivity may well have resulted from the use of slots greater than 
$\frac{1}{2}$ in. in length, and in any event a margin of safety would be provided if slots of $\frac{3}{4}$ in. length were used in preference to the $\frac{1}{2}$ in. slots.

As all these comparative tests were made with a single antigenic component of $M$. faeni, it does not follow that the same relative figures would have been obtained had the tests been made with an antigen of different molecular weight and electrical charge. In particular, the adverse impact of non- specific staining on the sensitivity of immunodiffusion tests would have been lessened had tests been $\vec{F}$ made with an antigen from which arcs of precipitation further away from the serum origin, had resulted.

\section{REFERENCES}

Jameson, J. E. (1968). J. clin. Path., 21, 376. (1969). Ibid, 22, 519. 